\title{
CRITICAL THEORY IN ENVIRONMENTAL EDUCATION: A SITUATED REVIEW OF EMERGING CRITICAL PROCESSES FOR MEDIATING LEARNING-LED CHANGE
}

\author{
Rob O'Donoghue'
}

\begin{abstract}
Critical theory is explored from origins in a process theory of social development after Marx, and into a diversity of discourses that have shaped critical work in education today. Within this broader picture, the emergence of critical theory in a South African context of environmental education is examined as developing narratives informing learning-led change. The study reviews how critical pedagogy proliferated in education imperatives with little evidence of the desired transformation. Immanent critique is used to track two intermeshed streams of critical theory namely, imperatives to facilitate emancipatory change and a democratizing shift to participatory inclusion (empowerment). Here the study notes how contextual reflexivity receded and an early emphasis on critical literacy was muted as critical pedagogy emerged as democratic processes of self-empowerment and transformative learning through participatory action research.

The review concludes with a brief examination of some process theories of learning in an attempt to reconcile narrowing disjunctures and to better situate environmental education as more open-ended critical processes of co-engaged learning.
\end{abstract}

Keywords: critical theory; critical pedagogy; transformative learning.

\section{TEORÍA CRÍTICA EN EDUCACIÓN AMBIENTAL: UNA REVISIÓN SITUADA DE LOS PROCESOS CRÍTICOS EMERGENTES PARA MEDIAR EL CAMBIO DIRIGIDO POR EL APRENDIZAJE}

\section{Resumen}

En este artículo, se busca explorar la teoría crítica, desde los orígenes, en una teoría procesal de desarrollo social a partir de Marx, y en una diversidad de discursos que moldearon el trabajo crítico en educación en los días actuales. Dentro de este escenario amplio, la emergencia de la teoría crítica en el contexto de África del Sur, en el ámbito de la educación ambiental, se examina como narrativas en desarrollo, informando cambios orientados por el aprendizaje. El estudio hace una revisión de cómo la pedagogía crítica proliferó en imperativos educativos con escasa evidencia de la transformación deseada. La crítica inmanente se utiliza para acompañar a dos corrientes impregnadas por la teoría crítica, que son imperativos para facilitar cambios emancipatorios y un cambio democratizante para la inclusión participativa (empoderamiento). Este estudio busca evidenciar, por medio de la pesquisa acción participativa, como la reflexividad contextual retrocedió y un énfasis inicial en alfabetización crítica fue silenciado, a medida que la pedagogía crítica emergió como un proceso democrático de auto-empoderamiento y aprendizaje transformador. Se concluye la revisión con un breve examen de algunas teorías procesales de aprendizaje, en un intento de conciliar divergencias y mejor situar la educación ambiental como un proceso crítico, más abierto, de aprendizaje solidario.

Palabras clave: Teoría Crítica. Pedagogía Crítica. Aprendizaje transformador.

\footnotetext{
${ }^{1}$ ELRC, Rhodes University
} 


\title{
TEORIA CRÍTICA EM EDUCAÇÃO AMBIENTAL: UMA REVISÃO SITUADA DE PROCESSOS CRÍTICOS EMERGENTES PARA MEDIAÇÃO DE MUDANÇAS ORIENTADAS PELA APRENDIZAGEM
}

\begin{abstract}
Resumo
Neste artigo, procura-se explorar a teoria crítica, desde as origens, em uma teoria processual de desenvolvimento social a partir de Marx, e em uma diversidade de discursos que moldaram o trabalho crítico em educação nos dias atuais. Dentro desse cenário amplo, a emergência da teoria crítica no contexto Sul-Africano de educação ambiental é examinada como narrativas em desenvolvimento, informando mudanças orientadas pela aprendizagem. O estudo faz uma revisão de como a pedagogia crítica proliferou em imperativos educacionais com escassa evidência da transformação desejada. A crítica imanente é utilizada para acompanhar duas correntes permeadas pela teoria crítica, quais sejam, imperativos para facilitar mudanças emancipatórias e uma mudança democratizante para inclusão participativa (empoderamento). Este estudo busca evidenciar, por meio de pesquisa ação participativa, como a reflexividade contextual retrocedeu e uma ênfase inicial em alfabetização crítica foi silenciada, à medida que a pedagogia crítica emergiu como um processo democrático de autoempoderamento e aprendizagem transformadora. Conclui-se o artigo com um breve exame de algumas teorias processuais de aprendizagem, numa tentativa de conciliar divergências e melhor situar a educação ambiental como um processo crítico, mais aberto, de aprendizagem solidária.
\end{abstract}

Palavras-chave: Teoria Crítica. Pedagogia Crítica. Aprendizagem transformadora.

If the symbols of a language were not to some extent congruent with reality, with the data they represent, humans could not survive. Their orientation would be flawed, their communication full of misunderstandings. (Elias, 1991:96) 


\section{Background on critical theory in a southern African context}

Historically it is notable that, within the contours of a globalizing modernity that is playing out in the post-colonial context of our work in South Africa, trajectories in critical theory are informing education practices for emancipation and empowerment. ${ }^{2}$ Here critical environmental education practice has commonly been shaped within the ideals of liberal humanism and by an ambiguous mix of Arcadian ecological dispositions and socio-economic rationalism. Emerging work with critical theory and associated pedagogy can be traced back to an early process theory of social development after Marx. This provided a foundation for the critical social theory that informed education responses to colonial and modernist exclusions. Lather (1995) notes how a combination of the critical theory of the Frankfurt School, counter-hegemonic practice after Gramsci and the critical literacy conscientisation of Freire variously constituted and framed a diversity of critical education trajectories. These narratives developed over time in imperatives for emancipation from marginalising oppression and were expanded to engage the social-ecological challenges of modernist cosmopolitan abjection ${ }^{3}$ and risk through environmental education.

\section{Situating a review of critical theory in education}

Although critical theory is commonly reflected as a singularity, its manifestations do not have a unitary root other than the early process theory of Marx, mentioned above, that began to infuse the development ideals of 20th Century economic rationalism with 'negative values' (critique). The later expansion of critical theory in education came to inform our work in South Africa where diverse narrative streams of theory were assimilated from elsewhere. Most notable early on were the critical pedagogy of emancipation from oppression (FREIRE, 1986) and critical education theory emanating from the North (STENHOUSE, 1975; MEZIROW, 1981 and GIROUX, 1983). Critical theory emerged within an expanding democratization and widening imperatives for transformation that developed with a succession of global environment, social justice and sustainability education initiatives (UNESCO) into the latter part of the $20^{\text {th }}$ Century (O'DONOGHUE, 2014). The circulation of these and other expanding streams came to be informed by critical education theory and were developed to inform our expanding education work in apartheid southern Africa.

This review of the emergence of critical theory is undertaken in the domain of education, with particular reference to environmental education in the South African context of our work. The research has been approached as a process of immanent critique seeking to examine the emergent contours of critical theory in environmental education imperatives and research from within. The review is thus centred on some of main contours in an expanding education domain of critical discursive practice as this shaped environmental education narratives and practices over a period of a little over 25 years. Here the study examines how key strands of critical theory emerged as critical perspectives for constituting learning-led, transformative change. Each of the interacting trajectories informing our work in southern Africa is examined for how these came to emerge within antecedent conditions that shaped

\footnotetext{
${ }^{2}$ The distinction between emancipation and empowerment is important here as critical theory has been appropriated into widening use in education with many ideas merging and ideals being blurred. For example, emancipatory critical literacy pedagogy after Paulo Freire was notable in South America but a more muted and individualized empowerment imperative emerged in the globalizing expansions that characterize critical theory in education today.

${ }^{3}$ Popkewitz (2008) probes the double gesture of hope and fear that shapes abjection as an exclusionary process in cosmopolitanism.
} 
the models of process towards change-orientated learning that we have come to work with in environmental education today.

The study traces how early critical education discourses began influencing environmental education in the 1980 s and proliferated in the early 1990 s before briefly receding to become more prominent again in postcolonial trajectories that have come to the fore in recent years. The review takes particular note of how some key dimensions of emerging critical education research and pedagogy were transformed or 'lost in translation' as a circulating and expanding corpus of critical theory was inscribed within and reshaped the prevailing political sociologies informing attempts at critical education praxis. Critical theory successively came to inform and shape environmental education and by extension, an expanding notion of Education for Sustainable Development and now the recent advent of Global Citizenship Education. The immanent critique is developed as a reflexive review of how critical theory emerged in a South African context to be transformed into the diverse and contested models of process for collaborative, learning-led social-ecological change and environmental justice that we have today.

\section{Literature informing the emergence of critical theory in Environmental Education}

History and emerging critical perspective have been foundational in the development of critical imperatives for contemplating social development (MENNELL, 1992) and are also integral to socio-cultural perspectives on learning (ENGESTRÖM; SANNINO, 2012), so it is not surprising that environmental education processes in southern Africa and elsewhere emerged as critical processes of socio-cultural reorientation in a changing modern world. Our early work with critical theory was inspired by the emancipatory texts of Paulo Freire (1986), providing us with an orientating perspective for critical pedagogy. His works were read alongside educational expansions of the action research oeuvre emanating from the earlier work of Kurt Lewin (1946) that resonated with the 'action-reflection' process proposed in the 'teacher as researcher' oeuvre in curriculum theory after Lawrence Stenhouse (1975). Neither of the latter perspectives make reference to critical theory but both have a critical edge informed by context and history, very much in line with early environmental education as this emerged as a critical process ${ }^{4}$ in our southern African context and came into conversation with critical theory in the 1980s.

The 1990s brought a surge of interest in critical theory, initially in adult education and expanding into environmental education. The Australian works on critical theory in education research (ROBOTTOM, 1987, ROBOTTOM; HART, 1993 and FIEN, 1993a \& 1993b.) and the Carr and Kemmis (1986) synthesis 'Becoming Critical's were read with numerous other texts on critical theory in education (GIROUX, 1983 and APPLE et al. 2009 for example). These perspectives on critical education research, curriculum and pedagogy came into widening use with the resolution of the 'paradigm wars' in environmental education research.

The paradigm wars were an intellectual conflict in research methodology that erupted in response to the dominance of positivism and functionalism in environmental education research at the time and played out in the North American Association of Environmental Education in the early 1990s (MRAZEK, 1993). Here critical theory came to be constituted as a research paradigm and was positioned in contrast to positivism and as an expansion of interpretive research. It was reflected as a situated and standpoint disposition for guiding

\footnotetext{
${ }^{4}$ Here a critical perspective (theory) was evident a critical reading of a changing world that emerged in collective dialogue and ethical commitment related to environmental degradation and emerging risk.

${ }^{5}$ Having already been confronted with some of the difficulties of conducting and realizing an emancipatory intent through action research, this text was received with a cautioning reserve.
} 
research and learning that had an emancipatory and transformative intent. The mediated inclusion of critical theory as an emerging research paradigm was developed out of a populist reading of Thoman Kuhn's, 1962 'structure of scientific revolutions' and critical environmental education research came to be located amongst an ordered array of research traditions that were said to be of equal merit and differing purpose (MRAZEK, 1993 \& 2003).

In this way, critical theory in environmental education was constituted as a reflexive critical process that enabled us to design research and develop pedagogy for emancipatory empowerment and transformation ${ }^{6}$ in response to the marginalizing and oppressive legacies of apartheid. The apartheid conditions and the transition to democracy in the early 1990s became a crucible for emerging critical education work constituted as participatory processes of action research for social-ecological transformation. In this way, for example, action research came into widening use in research on participatory resource development (O'DONOGHUE; MCNAUGHT, 1991) and collaborative curriculum change (LOTZ, 1995).

\section{The contours of a participatory turn in environmental education}

As a diversity of critical education perspectives developed in response to escalating social-ecological change, risk, inequality and injustice, functionalist processes of corrective educational initiatives to put things right, were initially orientated as interventions that were mediated from the centre (O'DONOGHUE, 1987). A participatory shift began to appear in small functional units like environmental education centres (O'DONOGHUE; TAYLOR, 1988) but soon became more apparent in widening institutional imperatives that were primarily directed at creating awareness of risk through an educational engagement of participants in open-ended critical processes of learning so that they might foster change for the better (O'DONOGHUE, 1993). Thus, after an early period of primarily state intervention through conservation education, environmental education and latterly education for sustainable development, reflect an increasing trend from 'top-down' interventions to a 'down-loading' of the reflexive critical imperative to civic processes where participants might be facilitated to give effect to change through co-engagement in reflexive social learning and action. (O’DONOGHUE, 2014).

\section{An emerging contestation for emancipatory transformation}

Critical theory initiatives are commonly contrasted with these early centre-toperiphery (top-down) approaches. An emerging critical turn in environmental education did, however, inform and shape the change to the more collaborative processes that followed early functionalism (O'DONOGHUE; NCNAUGHT, 1991) and happened alongside a transition to democratic governance. At the transition to democracy from the late 1980s into 1994, the education discourses of the ruling elite were primarily centred on nature awareness and problems related to the wise use of natural resources. These did not often include questions of colonial marginalization and racial oppression, questions that had to be confronted with metaphorical caution (O'DONOGHUE, 1987). This was not an easy transition as it was accompanied by a protracted contestation with the then Council for the Environment over the

\footnotetext{
${ }^{6}$ The discourse of empowerment and transformation was picked up in adult education after the work of Jack Mezirow. Although working with a similar focus on adult education and clearly influenced by Freire (DIRKX, 1998). Mezirow (1981) developed his theory and adult literacy practice and emancipation with scant reference to critical theory other than the communicative rationality of Habermas. His work on transformative learning can now be traced through to the framing of ESD competences (de HAAN, 2010) for effecting social change through learning to know, to do, to be and to live together as a framework for reflexive social learning and change in ESD (UNESCO, 2015)
} 
process and substance of a proposed curriculum for Environmental Education in Teacher Education. An immanent critique of Arcadian ecological idealism and contradictions in the curriculum process (O'DONOGHUE, 1994) brought the issues to a head and its national implementation was abandoned.

\section{Critical literacy, collaborative materials development and civic engagement in action research}

Into the 1990s a proliferation of socially critical approaches to environmental education began to reflect more collaborative and grass root orientations. Civic processes of critical literacy for empowerment and social justice developed in adult education as emancipatory models of process that were deliberated and take up into environmental education practice. In our work this approach was supported by the provision of learning materials that were commonly co-developed with teachers and published through Share-Net, a low cost printing initiative managed by the Wildlife and Environment Society of South Africa (WESSA) (See Share-Net (1992) adult literacy booklets on indigenous knowledge practices for example). The democratizing shifts in approach were directed at education practices that facilitated 'grass-root' environmental awareness, empowerment and change, primarily amongst the previously marginalized and oppressed.

On the community engaged action research side, one of the key texts on critical theory that informed our work was 'Action Research and Community Problem Solving' after Stapp and Wals (1993). This informed the development of water quality monitoring and the expansion of citizen science as ways of fostering environmental learning through civic engagement in local environmental problems. Action research thus became a new method in an expanding repertoire for environmental education in curriculum and community contexts. Much of this work was centred on a reflexive approach to research through locally engaged generative research that included participant-led change projects as a central feature of this work, notably in the Rhodes University, Gold Fields participatory course which reflected the mantra, 'we are all teachers and learners.'

\section{The emergence of a critical research paradigm in Environmental Education}

On the research design side, a paradigmatic review by Janse-vanRensburg (1995) mapped out the education research landscape to include a critical theory expansion for our continuing work in environmental education. Texts by Robottom and Hart (1993) and Lather (1986 and $\left.1995^{7}\right)$, amongst others, informed the break with positivism and constituted case study as a tradition that shaped an expanding scope of critical research into the present day. The research became successively more contextually situated and participatory with a transformative intent. An early emancipatory edge was muted with the transition to democracy in the mid 1990s and environmental education research was constituted as situated, critical, case study research. Here much of our critical theory was informed by the writings of Popkewitz, notably his 'political sociology of education reform' (1991) and critical 'history of the present' (2001). The works of Giroux (1983) and the emerging work of Apple (2009) were also widely read and came to inform a critical perspective in education research and practice that waxed and waned over the years.

\footnotetext{
${ }^{7}$ Note that this text is positioned as 'post-critical' at a time when the recursive, ideological determinism in early critical theory was being exposed.
} 


\section{Contradictions in a receding critical project}

In the late 1990s the rapid expansion of critical theory receded as post-apartheid liberal humanism muted the critical project amidst a soft paternalism 'for the Other' that left the position of the elite of the old guard intact and the new ruling elite relatively unchallenged. A receding of critical theory was evident in a sanitizing of action research as it lost an emancipatory edge and became a collaborative process of learner empowerment. This was accompanied by emerging uncertainty with the failure of collaborative critical projects to bring about the desired change. The critical education project has recently emerged again as the anticipated social transformation that democracy and freedom from apartheid oppression had promised, has not emerged with improved livelihoods and 'service delivery.' A resurgence of an expanding critical project is currently pointing to a lack of transformation, noting how liberal humanism has been implicated in continuing abjection in the modern cosmopolitan state.

\section{Synthesis and recent expansion}

The drivers of early critical imperatives, the attendant high hopes for emancipatory change and new co-engaged methodologies are, as noted above, characterized by limited transformative successes but increasing critical grasp of the complexities involved in learningled change. Seemingly divergent models of process for mediating social change drew on much the same literature to initially develop as intermeshed discourses involving:

- collaborative learning to get things back on track (empowerment) and

- critical social processes to transform the game (emancipation).

The two trajectories were by no means exclusive and became difficult to distinguish as participatory social learning initiatives characterised post-apartheid environmental education in the region. Latterly processes of civic mobilization for sustainability have been informed by theories of social-ecological resilience (OLSSON et al., 2015) and collaborative social learning in relation to the commons and environmental co-management (CUNDILL, 2010). These can all be seen as social-ecological and social justice trajectories in education that have developed as a compelling alternative to change as the arbitrary outcomes of the escalating conflict or the natural disasters that characterized change in earlier times.

Trends in critical theory in the southern African educational context under review were similar to widening trends in critical theory elsewhere. The similarities can be read in the broad contours scoped by Lotz-Sisitka (2015) who identified three broad phases, early critical theory after the 'Frankfurt School,' the communicative rationality and democratization after Habermas that followed and a third generation centred on a strengthening of emancipatory imperatives. More recently there has been a further proliferation of realist critical theory (BHASKAR, 2008) along with expansions into social the realism of Archer (2015). Each of these trajectories had recursive critical contours that expanded from the dialectical oeuvre of Marxian process theory and the modernist reflexive project that was taken up into the $20^{\text {th }}$ Century massification of education as a widening critical project of learning-led change. The patterns of change here enable some explanatory critique of the emerging contours of critical theory.

\section{Uncovering the recursive contours of early critical processes}

As briefly noted earlier, emancipatory critical perspective emerged within a critique of 
modernity that developed with an expansion of the Marxian oeuvre as this gave prominence to the uneven and unjust production and distribution of goods as material necessities for humanity to thrive. The early $20^{\text {th }}$ Century emphasis on the material heralded a break within the Germanic philosophies of the time that, for example, exemplified 'spirit' in philosophical theories of consciousness (Hegel). The shift to the material shaped the dualism of base (civic) and superstructure (state) as well as that of 'being' / 'consciousness' within a skeptical disposition that evoked critical narratives that were expanded into education imperatives. Mennell (1992) drawing on Elias for historical sociological perspective, notes how the Marxian break, was an outcome of a 'first great step' towards a process theory of social development but the inscribed dualisms came to shape a circular debate where:

It is not difficult to see that men are in no position to satisfy their elementary physical needs without thinking and without the knowledge to orientate themselves in their world, and that they are incapable of orientating themselves in this manner without satisfying their elementary needs. In other words, Marx's dialectical enthusiasm created a 'chickenand-egg' problem. (ELIAS 1977b: 128, my bold)

Cruickshank (2003) notes that a central proposition in the Marxian critical oeuvre is that:

Marx set out to examine capitalism on its own terms, and to see what problems emerged. (p.116)

Here he cites Gunn who points out that the central tenant of Marxian critical theory is immanent critique as it 'converses with its critical target' (capitalism) to uncover and to expose contradictions and paradox. He notes that in this way the critical process is a 'talk with one's opponent, to unravel their position from within.' The recursive difficulty here is that the classical Marxian critique of capitalism developed as a critical description of capitalism based on what was already held to be true, a political inscription that developed as a self-fulfilling circularity of criticism ${ }^{8}$. The critical imperative was always clear and often uncomfortable but difficult to enact educationally as emancipatory imperatives to facilitate change without a clear process theory of learning and change. In this way environmental education developed as models of process for the educational resolution of social-ecological risk but without an adequate grasp of the processes of learning for enacting the desired change. A process model for reflexive social change in modernity was uncovered by Beck (1992) in his 'Risk Society.' In this way, the critical project was appropriated into modernity as reflexive critical processes within environmental education as a process of learning-led change.

\section{An immanent critique of environmental education curriculum practice}

Early top-down environmental education models of process for fostering behavior change and their critical counterpoint for emancipatory praxis as a process of participatory action research were underpinned by a conventional wisdom that 'awareness creation" ${ }^{9}$ would enable learning so that the desired change would flow from this. The idea of creating awareness of risk was derived within an emerging ecological sciences vantage point. Here human activities were modelled as impacts on the environment and the environment was read as life-giving ecological systems and processes that when impacted by human activities produced risk. Awareness through these ecological insights developed in nature reserves so it

\footnotetext{
${ }^{8}$ A number of ways around this problem have emerged, the dialectic pulse of freedom after Bhaskar, Engeström's mirror data and expansive learning process as well as Popkewitz's 'history of the present.' These are explored later in the review.

${ }^{9}$ Awareness of natural systems / problems remains an underpinning mantra for most EE and ESD today.
} 
is not surprising that the roots of environmental education activities developed as nature experience processes that exposed the contradictions in human livelihood activities in cities and on farms that were producing risk.

In southern African environmental education, wildlife ecology was underpinned by an Arcadian fascination with the interdependence in nature, particularly in relation to the savannah wildlife habitats of Africa. The colonial scientific disposition was blind to the savannah grasslands as a cultural landscape shaped by earlier human activities of hunting, driving and fire (O'DONOGHUE, 1997). The contrast between humans and nature came into stark relief as wildlife preserves were created in the wake of a colonial slaughter of game and wildlife began to proliferate in game parks. It soon became evident the park habitats had to be managed with fire to mimic 'natural' processes as, for example, the savannah grasslands of the Hluhluwe-Umfolozi park were rapidly transitioning into woodland and thicket. So passionate was the ecological preservationist imperative to exclude human drivers a "natural processes' that extensive studies in KZN Wildlife, where I worked at the time, were blind to the socio-cultural evidence and concluded that lightning fires were the evolutionary drivers of the grasslands of southern Africa. These natural processes had shaped the savanna grasslands and their exclusion was encouraging the generation of moribund thicket. The overgrazing by native cattle remained one of the main threats to wildlife and education became a priority.

As participatory action research (PAR) approaches were more widely taken up in the 1990s, the resonant drive of the desired 'environmental awareness' in nature reserve environmental education programmes was the ecological sciences underpinned by the colonial pastoral ideal of thriving ungulates on the African savanna, a perspective that has been perpetuated to market an idealized African Eden of the international tourist trade today. It is thus not surprising that these colonial social imaginaries and awareness acquisition for self-empowerment through participation in nature experiences had little traction amongst indigenous peoples who constantly found themselves caught in a double bind. They were doomed to fail by taking up an idealized ecological quest that would deprive them of livelihood opportunities and were doomed to rural poverty by being denied access to the natural capital in nature reserves that had previously been included in their livelihood environments. In this way participatory action research processes of critical education practice (acquisition through participation) did not adequately engage or resolve social-ecological concerns through self-emancipation within the South African apartheid legacy of exclusion.

Read in a similar overview in curriculum contexts, it is notable that critical education imperatives emerging in schooling developed as a break from behavioural instrumentalism, to be constituted as dialectical processes of learner-led collaborative change. Here, for example, the change in perspective was informed by the Stenhouse (1979) critique of behaviourism to reframe curriculum as an historically constituted process theory (McKERNAN, 2008). The Stenhouse oeuvre in curriculum theory ${ }^{10}$ was read alongside a South-North synthesis of critical theory reflected in Carr and Kemmis (1986) and expanding into the 1990s within the proliferation of critical theory outlined earlier in this paper. The apparent break from the instrumentalism of behaviourist theory developed as a critical framing of curriculum and pedagogy towards environmental education as a process of collaborative social learning to be undertaken in developing context and in concert with learners (STENHOUSE, 1979). These changed perspectives on curriculum enabled environmental education as an emerging critical project to be taken up into Curriculum 2005, an outcomes-based education (OBE) process that despite two subsequent adjustments, has not played out the desired emancipatory

\footnotetext{
${ }^{10}$ At the Bertioga seminar on environmental education research Philip Payne explained how Wilfred Carr was appointed to Deakin University with a recommendation from Lawrence Stenhouse and how this gave impetus to the critical theory oeuvre in Australia at the time and extended into South Africa in Carr and Kemmis, (1986) .
} 
transformations. It was assumed that through engagement in critical curriculum praxis learners would come to emancipate themselves from prevailing dispositions (social habitus) as well as transcend structural constraints associated with these.

Read in critical relief, the ambivalence and failures here point to paradox in education as a critical process of self-actualising emancipation. Change did not readily develop through participant deliberation within habituated knowledge practices where sedimented disposition tended to pertain and the salvation narratives of Arcadian colonial idealism did not have cultural traction. Here also the early critical educational theory did not adequately narrate either the learning process for transcending sedimented disposition from within by coming to know things differently (knowledge acquisition) or for coming to satisfy elementary needs through the generative production of differing knowledge practices (participatory transformation). Sfard (1989) notes how metaphors of acquisition and participation have commonly been ambivalent and are often read as mutually exclusive in curriculum discourses on learning. She notes how both are necessary and, more recently, Edwards (2012) has developed a process model for learning within task sequencing in curriculum contexts that includes knowledge mediation (acquisition with/for participation) within an expansive process of collaborative learning-led agency (participation into learner-led social innovation).

Early environmental education as a critical environment and sustainability project orientated to foster social justice and change, played out as idealized political sociologies (ecological salvation narratives) for emancipation that were not sufficiently differentiated to narrate learning progessions where participants might come to enact the desired learning and change. Despite early efforts to develop a process model for 'active learning in OBE' (O'DONOGHUE, 1996), prevailing dispositions and entrenched patterns of practice remained surprisingly intractable.

Here also, in a narrow sense, the critical trajectory of European class struggles and unequal access to material goods that was implicit in early Marxian perspective does not directly resonate with globalizing processes of colonial oppression and the marginalizing exploitation of people and environment emerging from colonialism into the modern era. The expansion of the Marxian critical theory of class struggle in Europe to all other socio-cultural circumstances of oppressive marginalization is now being found wanting as these colonial contexts of socio-cultural disruption give rise to differing struggle dynamics related to the loss of dignity, widening human suffering and the environmental degradation that colonial modernity has wrought. Whereas this point is self-evident, the argument overlooks the emergent substance of dialogical reflexivity ${ }^{11}$ as an immanent critique of the processes driving exclusion in an expanded critical project that derived from and has been elaborated beyond the earlier Marxian oeuvre.

\section{Uncovering muting transformations in an expanding critical project}

Read in overview and drawing on some of the explanatory critique above, the expanding field of environmental education as a critical project has been somewhat betwixt and between in the emerging critique of imperial modernisation in southern Africa. Here environmental education developed as critical imperatives for change in response to ecological risk and then expanded to champion emancipatory critical processes of learning for change into the 1990s. In this way, modern education imperatives first emerged as functionalist interventions to put right things that were going wrong. The early top-down processes of education were successively subjected to deepening critique that sought

\footnotetext{
${ }^{11}$ The critical surfacing of contradictions and injustice is not driven by Marxian class struggle but immanent critique within the exclusionary injustices and 'epistemicides' of socio-historical and cultural abjection.
} 
emancipatory social justice through critical educational practices to resolve the marginalizing injustices of apartheid. These two corrective educational processes (interventions to put things right and education practices to change the game) are, as mentioned earlier, not exclusive yet are commonly conflated or opposed. The early critical trajectory was a corrective advancing of the frontiers of modernist ideals through attempts to mitigate its negative effects, whilst the critical emancipatory shift was an alienated engagement to correct the oppressive and marginalizing effects of the same imperial modernisation.

As critical theory, research and pedagogy developed in tandem and in tension action research emerged to effect transformations. This had two profound effects. The first was a process reduction of action research to a learner-led, participatory progression, Plan - Act Reflect. This primarily emanating from the North. The second, was an accompanying receding of a dialogical processes of critical literacy that had been promulgated in the originating work of Paulo Freire in the South.

\section{A receding of reflexive contextual reconnaissance in PAR}

It may seem strange for readers in South America and elsewhere to note how critical theory was constituted in environmental education research and pedagogy as action research, variously informed by expansive critical discourses that developed over time. Early action research in environmental education was a loose amalgam of the emancipation of Freire and the transformative intervention of Kurt Lewin. Much of Lewin's work was undertaken in North America and was constituted alongside the structural functionalism of Ralph Tyler. Here action research was developed as active citizenship (ADELMAN, 2006), a process of participant-engaged 'social engineering', to foster the democratic social integration of diverse peoples who had migrated to the 'new world' in the early $20^{\text {th }}$ Century ${ }^{12}$. In contrast to the South, the imperative was not initially a matter of worker and indigenous community liberation but a process for constituting the modern democratic communities of the modernist 'American Dream.' Only later was this expanded to include the empowerment of minorities suffering marginalizing abjection in the modern cosmopolitan state.

The educational appropriation of action research as critical pedagogy was accompanied by a process reduction of situated and emancipatory learning into a 'Plan - Act Reflect' sequence. Here a complex, contested and often uncomfortable process of critical discursive emancipation was condensed into a single entity, Participatory Action Research (PAR). Simply put, this developed through the process of critical action research becoming a noun and the education discourse became one of doing or implementing PAR. In this way the education practice became a facilitated collaboration to be enacted educationally as a democratic process for individual empowerment, a learner-led model of process that resonated with the democratic ideal of citizen empowerment inscribed in the American democratic project (liberal humanism).

It is notable how the socially critical project was somewhat muted here, particularly where an initiating critical reconnaissance of context ${ }^{13}$ to inform action research became implicit within the liberal democratic critical project. Exploratory contextual and reflexive work (reconnaissance) to derive a situated grasp of 'socially acute' ${ }^{14}$ questions had been a

\footnotetext{
${ }^{12}$ It is somewhat ironic that the colonial occupation of the lands of the indigenous cultures in North America should emerge as a crucible for an action research process of integrative re-orientation for waves of colonizing migrations from Europe and Latin America.

${ }^{13}$ Mayo (2013:11) note how researching the community and learning setting was central in the work of Freire to probe underlying contradictions and to frame a dialogical pedagogy.

${ }^{14}$ Isabel Martins used this term in conversation with me. It enables one to contemplate an issue of situated relevance or emerging in co-engaged research on local issues and the common good.
} 
key constituting process for the concept of action research emanating from the work of Kurt Lewin (1946). Here the initiating contextual engagement became subsumed and muted within a process reduced technical progression of Plan, Act Reflect, a cycle for learner-led democratically constituted change through PAR. In this way participatory action research was educationally reproduced as a collaborative learning sequence (pedagogy) for ${ }^{15}$ selfempowerment and change.

\section{A receding of a critical literacy of dialogical emancipation}

Critical literacy was at the heart of the liberation pedagogy of Paulo Freire, driving a dialogic process of inter-subjective critical engagement and civic mobilizing as emancipatory processes of learning-led change. Martins (2010) points out that:

Freire's philosophy of education was materialized in a literacy method for young people and adults which had at the heart the identification of the subjects' cultural vocabulary universe and of the social, political and existential situations in which these subjects take part. In his framework, such experiences give meaning to words and themes in a process that allows the awakening of a critical consciousness that leads to action and social change (p. 98)

His work became popularised within an expanding grand narrative of critical education (praxis) for empowerment through agentive processes of learning-led action research. Giroux (1983) and later Carr and Kemmis (1986) and Apple, Au and Gandin, (2009), for example, mapped out the curriculum and pedagogical contours for critical theory in education. The recursive ideals of emancipatory empowerment and transformation were, however, not accompanied by detailed process models of learning for contemplating and framing the contours of the desired learning-led change.

A more technical and narrower framing of transformative learning is notable in the works of Mezirow (1981). This drew on Habermas for critical orientation (with scant and later reference to Freire) and his work was developed through recursive cycles of empirical study that came to narrate a critical education process of transformative learning, primarily in adult education. ${ }^{16}$ Here, the framing of pedagogy for personal empowerment and social transformation exemplifies democratic deliberation and equity, key concerns in the context of the USA at a time of the abjection of minorities in the emerging cosmopolitan state. Here there was a notable muting of critical literacy as a civic dialogical process and transformative action is reflected as a facilitated process of personal empowerment.

In this way the early critical literacy pedagogy for emancipation after Shor and Freire (1987) receded as a dialogical critical process of education for emancipatory social justice. Critical 'reading to write' and 'writing to be read' in a widening 'grass root' enterprise emerged in expanding critical pedagogy as open-ended, rational discourses for selfempowerment and civic social change through Participatory Action Research (PAR). The literacy focus was still a central concern, primarily in the adult literacy movement but the originating critical literacy trajectory of situated dialogical politics was muted.

The above provides some broad brushstrokes of reductive processes in populist expansions of early critical theory through empirical education research to shape participatory imperatives for learner-led change that we have in diverse contexts of critical environmental education today.

\footnotetext{
${ }^{15}$ It is not a trivial matter that Paulo Freire entitled his book pedagogy 'of' and not 'for' to represent his conception of a situated and emergent critical literacy-led civic process of transformative social praxis.

16 This trajectory informed the specification of ESD competences by Gerhard de Haan that have come to frame the UNESCO imperative of transforming education (UNESCO, 2015 p.39).
} 


\section{An explanatory critique of muting transformations}

How these narrowing transformations occurred is relatively easily understood. As descriptive models of process for situated learning within an emergent critical literacy circulated, these were successively experienced in process-reduced abstractions towards the rational enactment of change within the democratic ideals of liberal humanism and as a process of collaborative social learning. The empirical abstraction of technical attributes for mediating democratic learning and change followed and notions of self-empowerment through literacy as transformative learning became a recursively constituted political sociology (MEZIROW, 1981). In this way expanding liberal humanist social imaginaries for collaborative learning and change in adult literacy brought widening perspectives on social learning as democratic processes of civic problem solving (STAPP; WALS, 1993 for example).

In these ways the desired environmental education processes for fostering change were increasingly idealized, derived, named, developed and enacted as entities through which participants might give effect to the desired change together, with the agency giving effect to change often being ascribed to the process-reducing models of inter subjective learning. In this way learning was modeled as rational sequences of learning-led change to be brought about through participatory action research. Participatory Action Research as a social imaginary for a democratic process of transformative social learning resonated within an expanding modernist ideology of liberal humanism and accompanying social imaginaries of environmental education were established as plan-act-reflect processes as an empowering rationale for learning-led change. Within these developing models of process, emerging ideals of collaborative learning became relatively blind to how empirical abstraction had stripped out of earlier ideals of contextual critical reflexivity and associated dialogical drivers emergent within the deliberative critical literacy of emancipation after Freire.

At the heart of the matter here is a situated processes of reflexive activity that might enable a critical distancing from the hegemony of prevailing 'common sense.' Educational work with critical theory will require more complete process models of situated critical literacy for reflexive socio-cultural learning to give rise to emancipatory processes of learning-led change. To conclude this review I give some attention to process theory as a neglected dimension of the critical educational work for emancipatory change in the modern era.

\section{Towards process models of learning that foreground context and critical literacy}

Assumptions that a desired end of 'behavior change' could be achieved through critical education praxis appear to have been ambivalent and unrealistically ambitious. For deliberation towards a fuller and more coherent critical education project ${ }^{17}$, it must first be noted that education can do little more than play a small part in a wider process of socioeconomic and political change. Secondly, it is unlikely that transformative learning can be successfully mediated without being situated with more coherent models of process for steering learning.

There are common threads here from the early process theory oeuvre of Marx into the

\footnotetext{
${ }^{17}$ As the recursive ideological drivers of early critical theory became evident much of the literature used the metaphor 'post-critical,' a popular dialectical move in postmodern times. In this review, whatever the metaphor the attendant shifts reflect a continuation of the critical project in another, often more robust and coherent guise but seldom making the attendant learning processes more explicit.
} 
proliferation of theory informing critical pedagogy today. The receding of the early situated and deliberative start-up drawn from Lewin and a loss of the elegant integration of context and critical literacy within the emancipatory work of Freire point to the need for process theories for informing agentive processes of learning-led change. Mezirow made some progress in this direction but empirical reductionism and the influences of the prevailing democratic individualism somewhat narrowed and muted a centrality of socio-cultural context and deliberative critical struggle in co-engaged action research processes of change. In tracking some of the ideals and theory driving critical education projects above, it became apparent that our continuing work would benefit from a review of process theory for learning that might more coherently reflected the emergence of situated knowledge practices, reflexive agency and learning-led change.

In a recent review of process theories of learning Engeström and Sannino (2012) note how early post behaviourist process theory were limited by presenting, one model of the learning process which is taken to be ideal and universally desirable. (p.50). These practices suffered a decoupling of the learning process from cultural context and the associated dialogical struggle in practice and shaping agentive meaning making towards possible change. They also note how there has been an exclusion of intentional instruction and that early process theory reflected self-fulfilling recursive processes notable in much of the application of critical theory in our education practice where learning was assumed to be implicit in and in line with the ideological intent of the critical imperative.

Working from the earlier work of Davydov in schooling, they review his idealtypical' learning sequence as a model of process with six learning actions. The orientating premise here is that:

"School children do not create the concepts, images, values and norms of social morality, but appropriate them in the process of learning activity. But, in performing that activity, school children realize thinking actions that are adequate to the actions by which these products of spiritual culture developed historically." (DAVYDOV, 2008, p. 121)

Before outlining a process theory of expansive learning as a similar ideal-type framing of epistemic actions they note that Davydov did not include critical questioning in his schema, possibly owing to the instruction styles of schooling at the time. They thus open with contextual questioning around emerging tensions and contradictions to contemplate an openended recursive model of process that involves:

- questioning, criticizing or rejecting some aspects of the accepted practice and existing wisdom.

- analyzing the situation. Analysis involves mental, discursive or practical transformation of the situation in order to find out causes or explanatory mechanisms. One type of analysis is historical-genetic; it seeks to explain the situation by tracing its origins and evolution. Another type of analysis is actual-empirical; it seeks to explain the situation by constructing a picture of its inner systemic relations.

- modeling the newly found explanatory relationship in some publicly observable and transmittable medium.

- examining the model, running, operating and experimenting on it in order to fully grasp its dynamics, potentials and limitations.

- implementing the model by means of practical applications, enrichments, and conceptual extensions.

- reflecting on and evaluating the process.

- consolidating the outcomes into a new stable form of practice.

(ENGESTRÖM; SANNINO, 2010, p. 51, my bold)

This open (and not necessarily linear progression) is a process model for learning that 
exemplifies both the situated dialogical critical processes exemplified by Freire and the similar deliberative socio-cultural contextuality of Lewin. The model goes on to exemplify emerging contradictions and a questioning transition to learning as an agentive track to deliberative change as a reflexive process emergent in context and thus providing relevance and articulation for those involved. Many of these contours for learning-led change have been implicit in participatory action research but have often been masked or overlooked as our critical imperative have not been accompanied by adequate models of process for contemplating how knowledge comes to us from others and we make it our own through meaning-making as a process of experiential re-semiotisation ${ }^{18}$ reflected in figure 1.

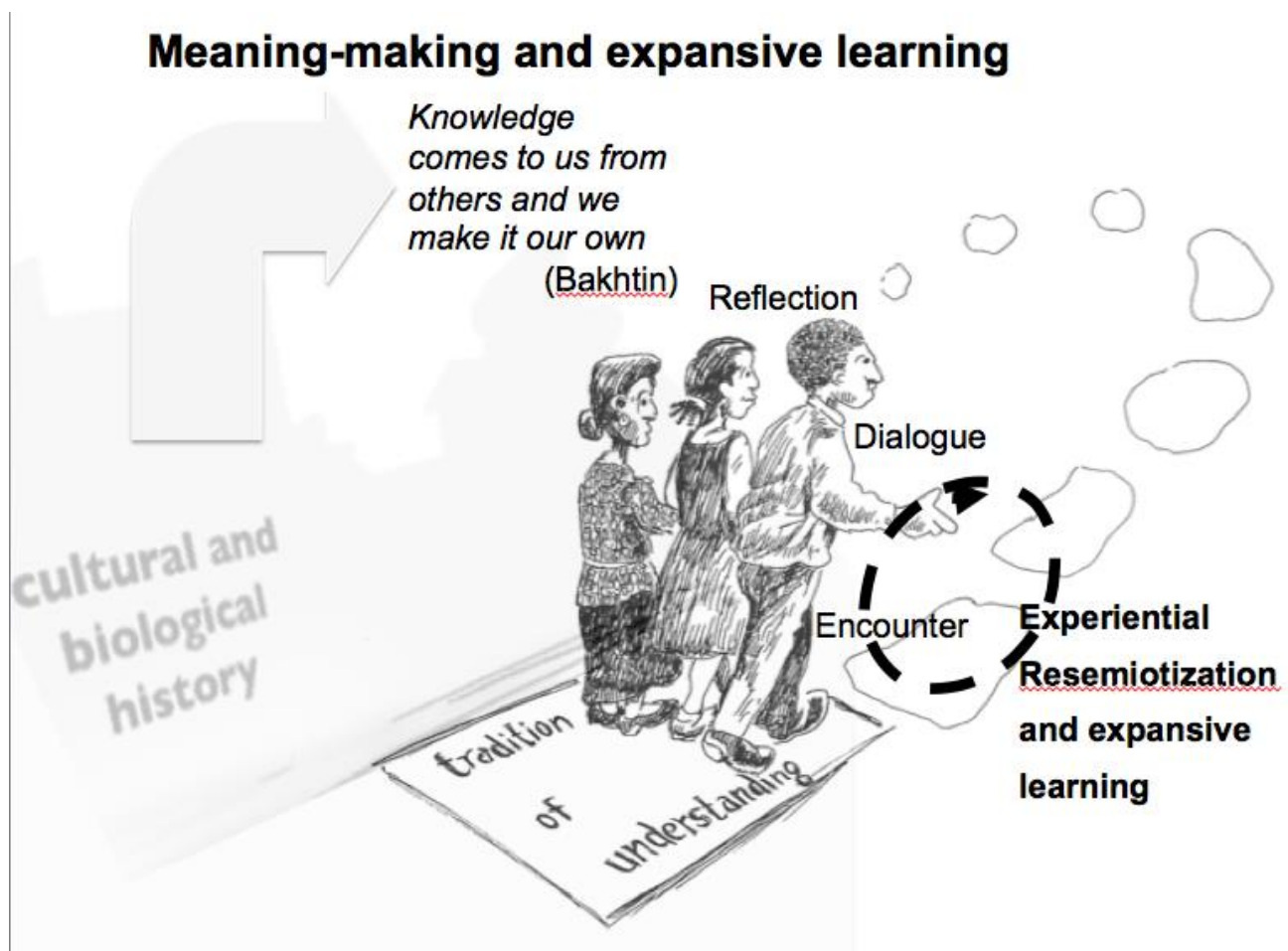

Figure 1: Experiential meaning-making.

In appropriating cultural orientations we acquire the means of communication as well as the cognitive structures for experiencing and mediating how our knowledge and dispositions resonate with others as well as animate and articulate ${ }^{19}$ with the living world that we share with other life support and living things. These critical process resonates with and extend the recursive critical oeuvre of Marx and most of the expansions that followed. Their strength resides with process theory that comes with an improved contextual capacity to contemplate and mediate change. Here the key elaboration that the Engeström and Sannino process model brings to critical theory is a reconceptualization of the critical project as a

\footnotetext{
${ }^{18}$ I am grateful to Isabel Martins for this insight and have attempted to elaborate this in an expansion of a process image of socio-cultural learning that has been doing the rounds for the last few years (origins unknown). ${ }^{19}$ Bruno Latour (1999) introduces the concept of articulation to chart the extent to which onto-epistemic propositions animate communicative engagement with and in the world of other living things, expanding the scope of communication with others.
} 
process of immanent critique emergent in contextual contradictions and developing as dialogical processes of reflexive activity to achieve a common purpose.

Today in our research in southern Africa and elsewhere, we face the challenges of colonial marginalization that has expanded within the modern globalising trajectories of exclusion that are being engaged within an emerging postcolonial critical literature. Here a critical interest in subaltern ontologies of marginalised loss and engagement in learning-led critical processes of change have once again exemplified the critical project as a situated process of reflexive transgression in the face of climate change in an Anthropocene of accelerated habitat change and biodiversity loss.

These processes are not easily understood without a grasp of contextual and cultural / historical complexities that we are normally relatively blind to in modern education. Here one needs to be open to finding and working with a rich array of social imaginaries and models of process for informing learning-led change in ways that might detour constraints on human freedoms and possible flourishing amidst the emerging global challenges of climate change. This may bring in a new and returning functionality within a realist reframing of critical theory as:

critical engagement in restoring and creating commonalities within a diverse set of logics that can be moved between and creatively deployed in identifying absences that might be absented to produce new or restored freedoms ${ }^{20}$.

The author would like to thank Isabel Martins, Heila Lotz-Sisitka and Flávia Torreão Thiemannfor critical support in this review of critical theory in environment and sustainability education research. Readings of contemporary literature, perspectives expressed and any oversights are entirely those of the author.

\section{References:}

ADELMAN, C. Kurt Lewin and the Origins of Action Research. Educational Action Research, Vol 1, n.1, p. 7-24, 2006.

APPLE, M. W.; AU, W.; GANDIN, L. A. The Routledge International Handbook of Critical Education. New York: Routledge, 2009.

ARCHER, M. (Ed) Generative Mechanisms Transforming the Social Order. London: Springer, 2015.

BECK, U. Risk Society: Towards a new modernity. London: SAGE, 1992.

BHASKAR, R. Dialectic the Pulse of Freedom. New York: Routledge, 2008.

\footnotetext{
${ }^{20}$ I have borrowed these concepts from the dialectical critical realism of Roy Bhaskar to reposition the critical project as an open social realist challenge but must leave any elaboration on his 'dialectic pulse of freedom' to further exploratory research.
} 
CARR, W.; KEMMIS, S. Becoming Critical: Education, knowledge and action research. Melbourne: Deakin University Press, 1986.

CRUICKSHANK, J. Realism and Sociology: Anti-foundationalism, ontology and social research. London: Routledge, 2003.

CUNDILL, G. Monitoring social learning processes in adaptive co-management: three case studies from South Africa. Ecology and Society v. 15, n. 3: 28, 2010. Disponível em: $\langle$ http://www.ecologyandsociety.org/vol15/iss3/art28/>.

de HAAN, G. The Development of ESD Related Competencies in Supportive Institutional Frameworks. International Review of Education 56 (2-3), p. 315-328, 2010. Disponível em: http://www.springerlink.com/content/ek411m104jwq7728/fulltext.pdf.

De SOUSA SANTOS, B. A Non-Occidentalist West? Learned Ignorance and Ecology of Knowledge. Theory, Culture and Society v. 12 (7-8) p. 1-3-125, 2009.

DIRKX, J. Transformative learning theory in the Practice of Adult Education: An Overview. PAACE Journal of Lifelong Learning, v. 7, p. 1-14, 1998.

EDWARDS, A. Designing Tasks which Engage Learners with Knowledge, In THOMPSON, I. (Ed) Task Design, Subject Pedagogy and Student Engagement. London: Routledge, 2014.

ELIAS, N. The Symbol Theory. University College Dublin Press, 1991.

ENGESTRÖM, Y.; SANNINO,A. Whatever happened to process theories of learning? Learning, Culture and Social Interaction, v. 1 pp. 45-56, 2012.

FREIRE, P. Pedagogy of the oppressed. New York: Continuum, 1968.

FIEN, J. Education for the Environment: Critical educational theorising and environmental education. Geelong: Deakin University, 1993a.

FIEN, J. Environmental Education and Social Change. Study Guide and Reader. Geelong: Deakin University, 1993b.

GIROUX, H. A. Theory and Resistance in Education: A Pedagogy for the Opposition. Westport: Bergin and Garvey, 1983.

JANSE-VANRENSBURG, E. Environmental Education and Research in Southern Africa: A landscape of shifting priorities. Unpublished PhD, Grahamstown, Rhodes University, 1995.

KUHN, T The Structure of Scientific Revolutions. Chicago: University of Chicago Press, 1962.

LATHER, P. Research as Praxis. Harvard Educational Review v. 56, n. 3, p. 257-277, 1986.

LATHER, P. Post-critical pedagogies: a feminist reading. In McLAREN, P., ed. Postmodernism, Postcolonialism and Pedagogy. Albert Park Australia: James Nicholas Publishers, 167-186, 1995.

LATOUR, B. Pandora's Hope: Essays on the Reality of Science Studies. London, Harvard University Press, 1999.

LEWIN, K. Action Research and Minority Problems. In LEWIN, G.W. (Ed.) Resolving Social Conflicts. New York: Harper and Row, 1946. 
LOTZ, H. B. The development of environmental education resource materials for junior primary education through teacher participation. Unpublished PhD thesis, University of Stellenbosch, 1995.

LOTZ-SISITKA, H. A Review of Three Generations of Critical Theory: Towards reconceptualsing critical HESD research". In Baarth, M., Michelsen, G., Rieckmann, M., \& Thomas, I. Routledge Handbook of Higher Education Research for Sustainable Development. London: Routledge. Pp. 207$222,2015$.

MAYO, P. Echoes from Freire for a Critically Engaged Pedagogy. New York: Bloomsbury, 2013.

McKERNAN, J. Curriculum and Imagination: Process theory, pedagogy and action research. New York: Routledge, 2008.

MENNELL, S. Norbert Elias: An Introduction. Oxford: Blackwell, 1982.

MEZIROW, J. A criticial theory of adult learning and education. In, Adult Education, v. 32, n. 1, p. 324, 1981.

MRAZEK, R., ed. Alternative paradigms in Environmental Education Research. In MARAZEK, R. ed. Monographs in Environmental Education and Environmental Studies, VIII. Troy Ohio: North American Association of Environmental Education, 1993.

MRAZEK, R. (2003) Retrospective: The decade following alternative paradigms in education research. Children, Youth and Environments. v. 13, n. 1 (Spring) ISSN 1546-2250.

O'DONOGHUE, R. B. Environments people and environmental education: A story of bananas, frogs and the process of change. Southern African Journal of Environmental Education, v.5 (August), p. 1114, 1987.

O'DONOGHUE, R. B. A grand plan for earth-love education in southern Africa: The dream becomes a nightmare. So, what went wrong? Southern African Journal of Environmental Education, v.14, p.3545, 1994.

O’DONOGHUE, R.B. Active Learning in OBE. Howick, Share-Net, 1996.

O'DONOGHUE, R.B. Detached Harmonies: A study in/on developing social processes of environmental education in eastern southern Africa. Unpublished $\mathrm{PhD}$ thesis, Grahamstown, Rhodes University, 1997.

O’DONOGHUE, R.B. Think Piece: Re-thinking Education for Sustainable Development as transgressive processes of educational engagement with human conduct, emerging matters of concern and the common good. Southern African Journal of Environmental Education. v. 30, 2014.

O'DONOGHUE, R.B.; TAYLOR, J. Towards participant-centred resource development for Environmental Education. Southern African Journal of Environmental Education, v.7, p. 3-5, 1988.

O'DONOGHUE, R. B.; MCNAUGHT, C. Environmental education: the development of a curriculum through 'grass roots' reconstructive action. Southern African Journal of Environmental Education, v. 10, p. 16-23, 1991.

O'DONOGHUE, R. B., TAYLOR, J.; CLACHERTY, A. A Critique of the Proposed Council for the Environment National Core Syllabus for Environmental Education in South Africa. Southern African Journal of Environmental Education, v. 13, p.39-44, 1993. 
O'DONOGHUE, R.B; LOTZ-SISITKA, H.B. Towards a better grasp of what matters in view of the 'posts'. Environmental Education Research. v.11, n.8, p.445-454, 2005.

OLSSON, L. JERNECK, A., THOREN, H., PERSSON, J.; O'BRYAN, D. Why resilience is unappealing to social science: Theoretical and empirical investigations of the scientific use of $\begin{array}{llll}\text { resilience. Ecology } & \text { 21(2):27. }\end{array}$ http://dx.doi.org/10.5751/ES-08450-210227, 2015.

POPKEWITZ, T. A political sociology of Education Reform: Power, Teaching, Teacher Education and Research. New York: Teacher College Press, 1991.

POPKEWITZ, T. Cultural History and Education: Critical essays on knowledge and schooling. New York: Routledge, 2001.

POPKEWITZ, T. Cosmopolitanism and the Age of School Reform: Science, Education and Making Society by Making the Child. New York: Routledge, 2008.

ROBOTTOM, I. (Ed) Environmental Education: Practice and Possibility. Geelong: Deakin University, 1987.

ROBOTTOM, I.; HART, P. Research in Environmental Education. Engaging the Debate. Geelong: Deakin University, 1993.

SFARD, A. On Two Metaphors for Learning and the Dangers of Choosing Just One. Educational Researcher, v. 27, n.2, p. 4-13, 1998.

SHARE-NET Indigenous Knowledge Adult Literacy Series. Howick, Share-Net, 1992.

SHOR, I.; FREIRE, P. A Pedagogy for Liberation: Dialogues on transforming education. Westport: Bergin and Garvey, 1987.

STAPP, W.; WALS, A.E.J. An action research approach to environmental problem-solving. In FIEN, J. AND SPORK, H., eds. Trends and Issues in Environmental Education: Study Guide and Reader. Victoria, Geelong: Deakin University Press, 170-179, 1993.

STENHOUSE, L. An Introduction to Curriculum Research and Development. London: Heinemann, 1975. 